\title{
Effect of alfalfa microbiota on fermentation quality and bacterial community succession in fresh or sterile Napier grass silages
}

\author{
Zhihao Dong, Tao Shao, Junfeng Li, Lili Yang, and Xianjun Yuan* \\ Institute of Ensiling and Processing of Grass, College of Agro-Grassland Science, Nanjing Agricultural University, Nanjing 210095, China
}

\begin{abstract}
The aim of this study was to reveal the reconstitution dynamics of alfalfa microbiota and their contribution to the fermentation quality of Napier grass silages. Napier grass was harvested at approximately $20 \%$ dry matter content, chopped to a theoretical length of cut of 2 to 3 $\mathrm{cm}$, and ensiled in laboratory polyethylene plastic bags $(400 \times 250 \mathrm{~mm})$ for $30 \mathrm{~d}$. The Napier grass was treated with the following: natural fermentation and distilled water (NG), inoculum of alfalfa microbiota (AM), gamma-ray irradiation and distilled water (IR), and gamma-ray radiation and alfalfa microbiota (IR+AM). Three milliliters of inoculum (containing $8.93 \mathrm{log} \mathrm{cfu}$ / $\mathrm{mL}$ lactic acid bacteria, $9.76 \mathrm{log} \mathrm{cfu} / \mathrm{mL}$ Enterobacteriaceae, $5.94 \log \mathrm{cfu} / \mathrm{mL}$ yeast, and $6.53 \log \mathrm{cfu} / \mathrm{mL}$ mold) eluted from equivalent fresh alfalfa $(450 \mathrm{~g})$ was added to each silo of AM and IR+AM treatments, and $3 \mathrm{~mL}$ of distilled water was added to the silo of the NG and IR treatments. Three triplicate silos per treatment were opened on $\mathrm{d} 1,3,5,7,14$, and 30 for sampling and analysis of fermentation quality and bacterial community. Relative to the NG silages, IR+AM silages exhibited a higher lactic acid concentration. The higher acetic acid concentration in NG than in IR+AM silages after $7 \mathrm{~d}$ of ensiling was attributed to the dominant genus of Leuconostoc (64.29-49.04\%). Adding alfalfa microbiota to sterile Napier grass could increase ammonia- $\mathrm{N}$ concentration compared with $\mathrm{NG}$ and IR silages after $3 \mathrm{~d}$ of ensiling. Leuconostoc was the most predominant genus in NG silages, followed by Lactobacillus. Pediococcus had a greater relative abundance than the indigenous microorganisms and was exclusively found in AM and IR+AM silages, whereas Lactobacillus exhibited a slight increase after $30 \mathrm{~d}$ of ensiling (relative abundance in each silage: 6.29 vs. $3.82 \%$, respectively). Lactobacillus was the predominant
\end{abstract}

Received May 14, 2019.

Accepted January 21, 2020.

*Corresponding author: hnyxj0702@163.com genus in IR silages since the onset of the ensiling. These results suggest that alfalfa microbiota affected bacterial community succession in Napier grass silages, which in turn affected the fermentation products. Adding alfalfa microbiota to sterile Napier grass could decrease acetic acid concentration compared with NG silages; however, it increased ammonia- $\mathrm{N}$ concentration compared with IR silages after $3 \mathrm{~d}$ of ensiling.

Key words: Napier grass, exogenous microbiota, bacterial community, fermentation quality

\section{INTRODUCTION}

Napier grass (Pennisetum purpureum Schumach) is one of the most promising grasses available for ruminant and bioenergy production in tropical and subtropical areas of China due to its high biomass yield of $40 \mathrm{t}$ of $\mathrm{DM} /$ ha (Li et al., 2018). However, the growth and harvest of grass are seasonal, leading to storage requirements to ensure a continuous supply for both ruminant and bioenergy production (Feng et al., 2018). Ensiling is an important method of preserving moist forage crops for extended periods while maintaining a nutritional value comparable with that of fresh forage. Fermentation is a microbial-driven process, and the fermentation quality of silages is highly dependent on the activities and types of microorganisms involved in the ensiling process (Peng et al., 2018).

Homolactic fermentation is more desirable than other types of fermentation because it results in a theoretical DM recovery of $100 \%$ and highly efficient production of lactic acid (LA), which reduces the $\mathrm{pH}$ of grass silages more quickly than other acids (Kung, 1998). Acetic acid (AcA), rather than LA, has usually been reported as the major fermentation product in tropical grass silages (Kim and Uchida, 1991). Nishino et al. (2012) observed that AcA concentration increased with prolonged ensiling, although LA fermentation initiated the ensiling of tropical grasses; it remains unclear why tropical grasses usually exhibited AcA-type fermentation. Kim and Uchida (1991) ascribed the AcA-type fermentation in Napier grass to the lower content of 
water-soluble carbohydrates (WSC) in tropical grass compared with temperate grass. Apart from the fermentable substrates, the microbiota also play an essential role in directing the fermentation process. In previous studies, single or combined inoculants were used to improve fermentation efficiency (Eikmeyer et al., 2013; Bao et al., 2016; Ogunade et al., 2017). However, to our knowledge, limited studies focus on the contribution of exogenous microbiota to the silage fermentation quality of forages.

Fecal microbiota transplantation inspired us to improve the fermentation quality of forages by exogenous microbiota (Staley et al., 2017). Fecal microbiota transplantation involves the transfer of the microbiota from the stool of a healthy individual to the intestinal tract of a recipient patient with dysbiotic microbiota. This procedure could reconstitute a normally functioning microbial consortium in recipient patients (Staley et al., 2017). Whether the exogenous microbiota could well adapt to and reconstitute in a new crop during the ensiling remains unknown. The results will provide the theoretical basis for exploiting potentially efficient, economical, and environmentally sound silage additives.

It was hypothesized that the transplantation of exogenous microbiota in recipient crops could reconstitute a microbial consortium that functions similarly to that found in the host crops during ensiling. Thus, this study was designed to reveal the adaptation process of alfalfa microbiota in Napier grass silages and the contribution of exogenous microbiota to fermentation quality of Napier grass silages. The alfalfa microbiota were added to sterile or nonsterile Napier grass, and the dynamics of fermentation and community succession during the ensiling of Napier grass were investigated.

\section{MATERIALS AND METHODS}

\section{Forage and Treatments}

Forage Harvest and Silage Preparation. Napier grass and alfalfa were cultivated in 5 plots of the experimental field of Nanjing Agricultural University $\left(32.04^{\circ} \mathrm{N}, 118.88^{\circ} \mathrm{E}\right)$. Three plots of each forage were harvested and pooled. Napier grass and alfalfa were harvested at the vegetative stage $(\sim 20 \% \mathrm{DM})$ and early bloom stage $(\sim 25 \% \mathrm{DM})$, respectively. Then, the fresh Napier grass and fresh alfalfa were chopped into lengths of 2 to $3 \mathrm{~cm}$ with a stationary machine (Sh2000, Shanghai Donxe Industrial Co. Ltd., Shanghai, China) and mixed thoroughly.

Inoculum Preparation. The inoculum was prepared as described by Mogodiniyai Kasmaei et al. (2017) with modification. First, $20 \mathrm{~kg}$ of fresh alfalfa was divided into $150-\mathrm{g}$ portions, and then each portion was processed to prepare the inoculum. A volume of $900 \mathrm{~mL}$ of quarter-strength Ringer's solution fortified with Tween 80 at $0.5 \mathrm{~mL} / \mathrm{L}$ was added to each portion (150 g) of alfalfa (Mogodiniyai Kasmaei et al., 2017). Then, the samples were kept in an orbital shaker at 150 rpm for $2 \mathrm{~h}$ and centrifuged at 15,500 $\times g$ for $90 \mathrm{~min}$ at $4^{\circ} \mathrm{C}$. The supernatants were discarded, and all of the pellets were pooled and resuspended in $120 \mathrm{~mL}$ of quarter-strength Ringer's solution.

Reconstitution of Alfalfa Microbiota in Napier Grass. Approximately $450 \mathrm{~g}$ of chopped Napier grass per replicate was treated with the following: natural fermentation and distilled water (NG), inoculum of alfalfa microbiota (AM), gamma-ray radiation and distilled water (IR), and gamma-ray radiation and alfalfa microbiota (IR+AM). Three milliliters of inoculum was injected into each silo of the AM and IR+AM treatments. To ensure that the ratio of fresh matter to epiphytic microbial population in reconstituted Napier grass and fresh alfalfa was equal, $3 \mathrm{~mL}$ of inoculum [containing (per mL) 8.93 log cfu of lactic acid bacteria (LAB), $9.76 \log$ cfu of Enterobacteriaceae, $5.94 \mathrm{log}$ cfu of yeast, and $6.53 \mathrm{log}$ cfu of mold] was eluted from 450 $\mathrm{g}$ of fresh alfalfa as estimated on the basis of 2 assumptions: (1) the microbial population was entirely removed from the fresh alfalfa and was evenly distributed in the liquid fraction, and (2) recovery of the microbial population from centrifugation was $90 \%$. An equal volume of distilled water $(3 \mathrm{~mL})$ was added to each silo of the NG and IR treatments. The chopped Napier grass (450 g) was manually packed into polyethylene plastic bags with an initial density of $0.525 \mathrm{~g} / \mathrm{cm}^{3}$ (dimensions: 400 $\times 250 \mathrm{~mm}$; embossed food saver bag; Taizou Wenbwu Soft-Packing Color-Printing Co. Ltd., Zhejiang, China). A total of 72 plastic bags were equally divided into 2 sets: one set (36 bags) was sterilized using a ${ }^{60} \mathrm{Co}$ source with an absorbed dose of $15 \mathrm{kGy}$ for $5 \mathrm{~h}$ (Xiyue Technology AG Co. Ltd., Nanjing, China) and designated as the gamma-ray radiation treatment (IR and IR+AM), and the other set was not sterilized and was designated as the nonsterile treatment ( $\mathrm{NG}$ and $\mathrm{AM}$ ).

After irradiation, bags were opened, and $3 \mathrm{~mL}$ of sterile distilled water or inoculum was applied to sterile Napier grass using an airbrush spray followed by thorough mixing by hand in each bag. All of these operations were carried out in a laminar flow cabinet, avoiding contamination. Then, the plastic bags were subject to vacuum and sealed with a vacuum sealer (DZD-400, Nanjing Aomitai Technology Co. Ltd., Nanjing, China). Silos were stored at room temperature $\left(\sim 25^{\circ} \mathrm{C}\right)$, and triplicate silos per treatment were sampled after $1,3,5$, 7,14 , and $30 \mathrm{~d}$ of ensiling. 


\section{Analyses of Organic Acid, Nutritional Composition, and Microbial Population}

Three random silos per treatment were opened at the designated ensiling time. Then, the ensiled forage was placed into an ethanol-disinfected plastic container and mixed thoroughly. Pre-ensiled and ensiled forages (80 $\mathrm{g}$, wet basis) were dried in a forced-air oven at $65^{\circ} \mathrm{C}$ for $48 \mathrm{~h}$ to measure the DM content. Dried samples were milled to pass the 1-mm screen of a laboratory knife mill (FW100, Taisite Instrument Co. Ltd., Tianjin, China). Milled samples were analyzed for total N, WSC, NDF, and ADF. The content of total $\mathrm{N}$ was determined using a Kjeldahl N analyzer (Kjeltec 8400 Analyzer, Foss Analytical AB, Höganäs, Sweden), and CP was calculated by multiplying total $\mathrm{N}$ by 6.25 (Krishnamoorthy et al., 1982). The WSC content was analyzed by colorimetry after reaction with anthrone reagent (Thomas, 1977). The NDF and ADF of fresh material were measured using an Ankom 200 fiber analyzer (Ankom Technologies, Macedon, NY) according to the procedures (Van Soest et al., 1991), and heat-stable $\alpha$-amylase was used in the NDF procedure. The results were expressed on a DM basis, including residual ash (Mertens, 2002).

Subsamples (20 g, wet basis) of ensiled forage were diluted with $60 \mathrm{~g}$ of distilled water and stored at $4^{\circ} \mathrm{C}$ for $24 \mathrm{~h}$. Then, silage extract was filtered through 4 layers of cheesecloth and Whatman filter paper (Xinhua Co. Ltd., Hangzhou, China). The $\mathrm{pH}$ of extract was immediately analyzed with a glass electrode $\mathrm{pH}$ meter (Hanna pH 211, Hanna Instruments Italia Srl, Padova, Italy). About $5 \mathrm{~mL}$ of the silage extract was used to measure the ammonia- $\mathrm{N}$ according to the phenolhypochlorite procedure (Broderick and Kang, 1980). About $10 \mathrm{~mL}$ of the silage extract was centrifuged at $10,000 \times g$ for $10 \mathrm{~min}$ at $4^{\circ} \mathrm{C}$, and the supernatant was reserved for organic acid analyses. Organic acids were quantified using an HPLC system (Agilent HPLC 1260, Agilent Technologies Inc., Waldbronn, Germany) fitted with a refractive index detector (column: Carbomix H-NP5, Sepax Technologies Inc., Newark, DE; eluent: $2.5 \mathrm{mmol} / \mathrm{L} \mathrm{H}_{2} \mathrm{SO}_{4}, 0.5 \mathrm{~mL} / \mathrm{min}$; temperature: $55^{\circ} \mathrm{C}$ ). The buffering capacity of fresh material was determined using the hydrochloric acid-sodium hydroxide method (Lin et al., 1992).

Subsamples $(10 \mathrm{~g})$ of each fresh or silage sample were shaken with $90 \mathrm{~mL}$ of sterile sodium chloride solution $(0.85 \%, 90 \mathrm{~mL})$ at $150 \mathrm{rpm}$ for $2 \mathrm{~h}$. One milliliter of solution was used for 10-fold serial dilution for microorganism counting, and then the remaining solution was filtered through 4 layers of medical gauze and stored at $-20^{\circ} \mathrm{C}$ for DNA extraction. Microorganism counts were performed in triplicate using the plate count methods.
Lactic acid bacteria were counted on De Man, Rogosa and Sharpe agar after $48 \mathrm{~h}$ of incubation at $37^{\circ} \mathrm{C}$ under anaerobic conditions. Enterobacteriaceae were counted on violet red bile glucose agar after $24 \mathrm{~h}$ of incubation at $37^{\circ} \mathrm{C}$ under aerobic conditions. Yeast and mold were counted on potato dextrose agar after 2 to $3 \mathrm{~d}$ of incubation at $28^{\circ} \mathrm{C}$ under aerobic conditions. The microbial data were obtained as colony-forming units and were transformed to a logarithmic scale on a fresh weight (FW) basis.

\section{Bacterial DNA Extraction, PCR Amplification, and Sequencing}

The solution for DNA extraction was centrifuged at $10,000 \times g$ for $15 \mathrm{~min}$ at $4^{\circ} \mathrm{C}$, which was carried out using a TIANamp Bacteria DNA isolation kit (DP302-02, Tiangen, Beijing, China) following the protocol provided by the manufacturer. The quantity and quality of DNA were evaluated using a NanoDrop 2000 UV-visible spectrophotometer (Thermo Scientific, Wilmington, DE). The DNA extracts of IR silages on $\mathrm{d} 1$ and 3 did not meet the standard set for highquality DNA in the experiment, which is characterized by an A260/280 ratio between 1.8 and 2.0; therefore, they were discarded. Thus 5-, 7-, and 30-d IR silages were used for high-throughput sequencing. For other treatments, 3-, 7-, and 30-d silages were used for highthroughput sequencing.

The V3-V4 regions of the 16S rRNA gene were amplified based on the specific primers 338F (ACTCCTACGGGAGGCAGCAG) and 806R (GGACTACHVGGGTWTCTAAT). Ten nanograms of genomic DNA was amplified using the following PCR conditions: 3 min of denaturation at $95^{\circ} \mathrm{C} ; 27$ cycles of $30 \mathrm{~s}$ at $95^{\circ} \mathrm{C}$, $30 \mathrm{~s}$ for annealing at $55^{\circ} \mathrm{C}$, and $45 \mathrm{~s}$ for elongation at $72^{\circ} \mathrm{C}$; and a final extension at $72^{\circ} \mathrm{C}$ for $10 \mathrm{~min}$ (Yang et al., 2019). The resulting PCR products were extracted from a 2\% agarose gel, and then they were purified using an AxyPrep DNA Gel Extraction Kit (Axygen Biosciences, Union City, CA) and quantified using QuantiFluor-ST (Promega, Madison, WI) according to the manufacturer's protocol. The PCR products were sequenced using the Illumina MiSeq PE300 platform (Illumina Inc., San Diego, CA). All raw reads were checked using FLASH (version 1.2.11, http://ccb.jhu .edu/software/FLASH/index.shtml), and low-quality sequences (quality scores $<20$ ) were discarded according to the QIIME quality control process (version 1.7.0, http://qiime.org/index.html). Operational taxonomic units were first clustered with a $97 \%$ similarity cutoff using Usearch (version 7.0; http://drive5.com/ uparse/). Then, the chimeric sequences were identi- 
Table 1. Nutritional and microbial populations in pre-ensiled samples

\begin{tabular}{lcccc}
\hline Item & $\begin{array}{c}\text { Napier } \\
\text { grass }\end{array}$ & Alfalfa & $\begin{array}{c}\text { Sterile Napier } \\
\text { grass }\end{array}$ & $P$-value $^{1}$ \\
\hline $\mathrm{DM}, \%$ of $\mathrm{FW}^{2}$ & 21.3 & 24.8 & 20.7 & 0.474 \\
Water-soluble carbohydrate, \% of DM & 13.4 & 9.9 & 13.1 & 0.650 \\
CP, \% of DM & 8.28 & 27.7 & 7.99 & 0.640 \\
Buffering capacity, mEq/kg of DM & 61.4 & 222 & 60.8 & 0.928 \\
ADF, \% of DM & 29.6 & 20.8 & 28.7 & 0.826 \\
NDF, \% of DM & 52.0 & 44.0 & 51.8 & 0.963 \\
Lactic acid bacteria, log cfu/g of FW & 7.76 & 6.75 & ND & - \\
Enterobacteriaceae, log cfu/g of FW & 6.34 & 7.58 & ND & - \\
Yeast, log cfu/g of FW & 3.98 & 3.76 & ND & - \\
Mold, log cfu/g of FW & 4.48 & 4.35 & ND & - \\
\hline
\end{tabular}

${ }^{1} P$-value for sterile versus fresh Napier grass.

${ }^{2}$ Fresh weight.

${ }^{3}$ Not detected.

fied and removed using UCHIME (uparse-cluster_otus meta_derepprefix_sorted.fasta -otus otu_0.97/cluster. fasta -otu_radius_pct 3). Community structure was analyzed at the phylum and genus levels using the Silva database (release 128; http://www.arb-silva.de) with a confidence threshold of $70 \%$. The Bray-Curtis dissimilarity metric was constructed and then visualized via nonmetric multidimensional scaling. The highthroughput sequencing data were analyzed using the free online Majorbio I-Sanger Cloud Platform (www.i -sanger.com).

\section{Statistical Analysis}

The effects of gamma-ray irradiation, alfalfa microbiota, number of ensiling days, and their interactions on fermentation characteristics were investigated in a $2 \times 2 \times 6$ factorial design using PROC MIXED of SAS (version 9.3; SAS Institute Inc., Cary, NC) in accordance with the model

$$
\begin{aligned}
\mathrm{Y}=\mu & +\mathrm{IR}_{\mathrm{i}}+\mathrm{AM}_{\mathrm{j}}+\mathrm{D}_{\mathrm{k}}+(\mathrm{IR} \times \mathrm{AM})_{\mathrm{ij}} \\
& +(\mathrm{IR} \times \mathrm{D})_{\mathrm{ik}}+(\mathrm{AM} \times \mathrm{D})_{\mathrm{jk}} \\
& +(\mathrm{IR} \times \mathrm{AM} \times \mathrm{D})_{\mathrm{ijk}}+\mathrm{e}_{\mathrm{ijk} \mathrm{kl}},
\end{aligned}
$$

where $\mathrm{Y}$ is the dependent variable; $\mu$ represents the overall mean; $\mathrm{IR}_{\mathrm{i}}$ is the fixed effect of gamma-ray irradiation ( $\mathrm{i}=2$, with vs. without); $\mathrm{AM}_{\mathrm{j}}$ is the fixed effect of alfalfa microbiota $\left(\mathrm{j}=2\right.$, with vs. without); $\mathrm{D}_{\mathrm{k}}$ refers to the fixed effect of length of ensiling $(\mathrm{k}=1,3,5,7$, 14 , or $30 \mathrm{~d}) ;(\mathrm{IR} \times \mathrm{AM})_{\mathrm{ij}},(\mathrm{IR} \times \mathrm{D})_{\mathrm{ik}},(\mathrm{AM} \times \mathrm{D})_{\mathrm{jk}}$, and $(\mathrm{IR} \times \mathrm{AM} \times \mathrm{D})_{\mathrm{ijk}}$ are the effects of interactions; and $\mathrm{e}_{\mathrm{ijk}}$ is the residual error. Tukey's multiple comparisons (statistical significance was declared at $P<0.05$ ) were conducted to compare differences among means.

\section{RESULTS}

\section{Characteristics of Forage Before Ensiling}

The nutritional and microbial compositions of alfalfa and fresh and sterile Napier grass are shown in Table 1. The contents of WSC, CP, ADF, and NDF of fresh Napier grass were $13.4,8.28,29.6$, and $52.0 \%$ of DM, respectively. There were no differences in nutritional composition between fresh and sterile Napier grass. No viable microorganisms were detected in Napier grass after gamma-ray irradiation. Alfalfa contained lower desirable LAB (6.75 log cfu/g of FW) and higher Enterobacteriaceae (7.58 log cfu/g of FW) counts than fresh Napier grass.

\section{Fermentation Profile of Napier Grass Silages}

The effects of alfalfa microbiota on $\mathrm{pH}$ value and organic acid concentrations of Napier grass silages are shown in Table 2. A 3-way interaction prevailed among gamma-ray irradiation, alfalfa microbiota, and number of ensiling days for $\mathrm{pH}$ value, concentrations of LA and AcA, and the LA:AcA ratio $(P<0.001)$. The AcA concentration increased $(P<0.001)$ with prolonged Napier grass ensiling, and gamma-ray irradiation $(P$ $<0.001$ ) decreased the AcA concentration (Supplemental Figure S1; https://doi.org/10.3168/jds.2019 -16961). The $\mathrm{pH}$ in IR silages was the highest during $3 \mathrm{~d}$ of ensiling, and then it became the lowest among all silages. There was an interaction among gamma-ray irradiation, alfalfa microbiota, and number of ensiling days for LA concentration because alfalfa microbiota increased LA concentration of nonsterile Napier grass silages (NG vs. AM) during the initial $14 \mathrm{~d}$ of ensiling, whereas the higher LA concentration in IR+AM than in IR occurred only at d 5 and 7 of ensiling (Supple- 
mental Figure S1; https://doi.org/10.3168/jds.2019 -16961). A 3-way interaction existed among gamma-ray irradiation, alfalfa microbiota, and number of ensiling days for AcA concentration because alfalfa microbiota increased AcA concentration of sterile Napier grass silages (IR+AM vs. IR), whereas no significant difference in AcA concentration was observed between NG and AM silages over the $30 \mathrm{~d}$ of ensiling (Supplemental Figure S1; https://doi.org/10.3168/jds.2019-16961). The LA:AcA ratio was higher in AM silage than in NG silages on $\mathrm{d} 3$ and 5 , whereas no significant difference in LA:AcA ratio was observed between IR and IR+AM silages.

The changes in DM, ammonia-N, and WSC contents of Napier grass silages are displayed in Table 3. The interaction of alfalfa microbiota and number of ensiling days existed for DM and ammonia- $\mathrm{N}(P<0.01)$ contents. Three-way interactions among gamma-ray irradiation, alfalfa microbiota, and number of ensiling days existed for ammonia-N $(P=0.009)$ contents. The alfalfa microbiota increased the ammonia- $\mathrm{N}$ contents of both sterile (IR+AM vs. IR) and nonsterile (AM vs. NG) Napier grass silages after $3 \mathrm{~d}$ of ensiling except at $7 \mathrm{~d}$. There was an interaction among gamma-ray irradiation, alfalfa microbiota, and number of ensiling days for WSC concentration because the WSC concentration in IR+AM silages was always smaller than that in IR silages, whereas the WSC concentration in AM silages was higher than that in NG silages after $14 \mathrm{~d}$ of ensiling (Supplemental Figure S2; https://doi.org/10.3168/ jds.2019-16961). The content of WSC decreased $(P<$ $0.001)$ with prolonged ensiling. The WSC contents in IR and IR+AM silages were higher $(P<0.05)$ than those in NG and AM silages over the ensiling period, respectively. The decrease in WSC in IR silages was initiated from d 5 of ensiling.

Changes in the Enterobacteriaceae and LAB populations in Napier grass silages are illustrated in Figure 1. The LAB in IR silages could not be detected until d 5 of ensiling, followed by a slight increase with small fluctuations. Enterobacteriaceae was not detected in IR silages over the ensiling. The Enterobacteriaceae population in $\mathrm{AM}$ and IR+AM silages decreased from 7.81 and 7.90, respectively, to an undetectable level during the initial $3 \mathrm{~d}$ of ensiling, whereas that in NG silages was absent after $5 \mathrm{~d}$ of ensiling.

\section{Bacterial Community Composition and Diversity in Napier Grass Silages}

A total of 2,085,400 quality sequence reads with an average length of 449 bp were generated by highthroughput amplicon sequencing of the $16 \mathrm{~S}$ rRNA gene (V3-V4 regions) in 6 fresh forage and 36 silages samples (Table 4), and these reads were clustered into a total of 327 operational taxonomic units based on a $97 \%$ sequence identity threshold. Rarefaction curves approached the plateau phase for all samples (data not shown), indicating that the number of reads was sufficient for identifying operational taxonomic units. The average Good's coverage (Table 4) for all samples was greater than $99 \%$, indicating that the sequencing depth was adequate for reliable analysis of the bacterial community. The Chaol and Shannon indices in fresh Napier grass were greater than those of fresh alfalfa $(P<0.05)$. The gamma-ray irradiation decreased the Shannon index and Chaol value, indicated by the lowest $(P<0.05)$ Shannon index and Chao1 values in IR silages.

As indicated in nonmetric multidimensional scaling $\left(\mathrm{R}^{2}=0.7821, P=0.001 ;\right.$ Figure 2$)$, both fresh alfalfa and fresh Napier grass were separately clustered with silages. The AM and IR+AM silages were clustered in the second quadrant, and the distinctions in bacterial communities between AM and IR+AM silages were unclear because the plots were clustered. The NG silages were separately assigned to the fourth quadrant, whereas IR silages were assigned to the first quadrant.

The succession of the bacterial community on the phylum level during the ensiling of Napier grass is illustrated in Figure 3. The microbiota in alfalfa before ensiling consisted of 3 predominant phyla: Firmicutes (62.98\%), Proteobacteria (26.64\%), and Cyanobacteria (10.26\%). Proteobacteria (64.91\%) was the most predominant phylum in fresh Napier grass, followed by Cyanobacteria (16.96\%), Firmicutes, (6.60\%), and Actinobacteria (6.28\%). Firmicutes became predominant during the ensiling of Napier grass.

The bacterial genera identified during the ensiling of Napier grass are demonstrated in Figure 4. There were 16 genera each with a relative abundance greater than $1 \%$ in fresh Napier grass, whereas fresh alfalfa had only 7 genera with a relative abundance greater than $1 \%$. This supported the observed higher bacterial diversity in Napier grass than in alfalfa before ensiling. Pantoea (28.74\%) was the most abundant genus in the Napier grass before ensiling, whereas Enterococcus (42.81\%) was the most predominant genus in fresh alfalfa. Leuconostoc remained predominant in NG silages during ensiling, followed by Lactobacillus. Pediococcus had a greater relative abundance than the indigenous microorganisms in Napier grass and became predominant in the ensiling of AM and IR+AM silages, where Lactobacillus showed a slight increase after $30 \mathrm{~d}$ of ensiling (relative abundance in each silage: 6.29 vs. $3.82 \%$, respectively). For the IR silages, Lactobacillus was the predominant genus since the onset of ensiling. The predominant bacterial components of silages from dif- 
Dong et al.: EFFECT OF EXOGENOUS MICROBIOTA ON NAPIER GRASS SILAGES

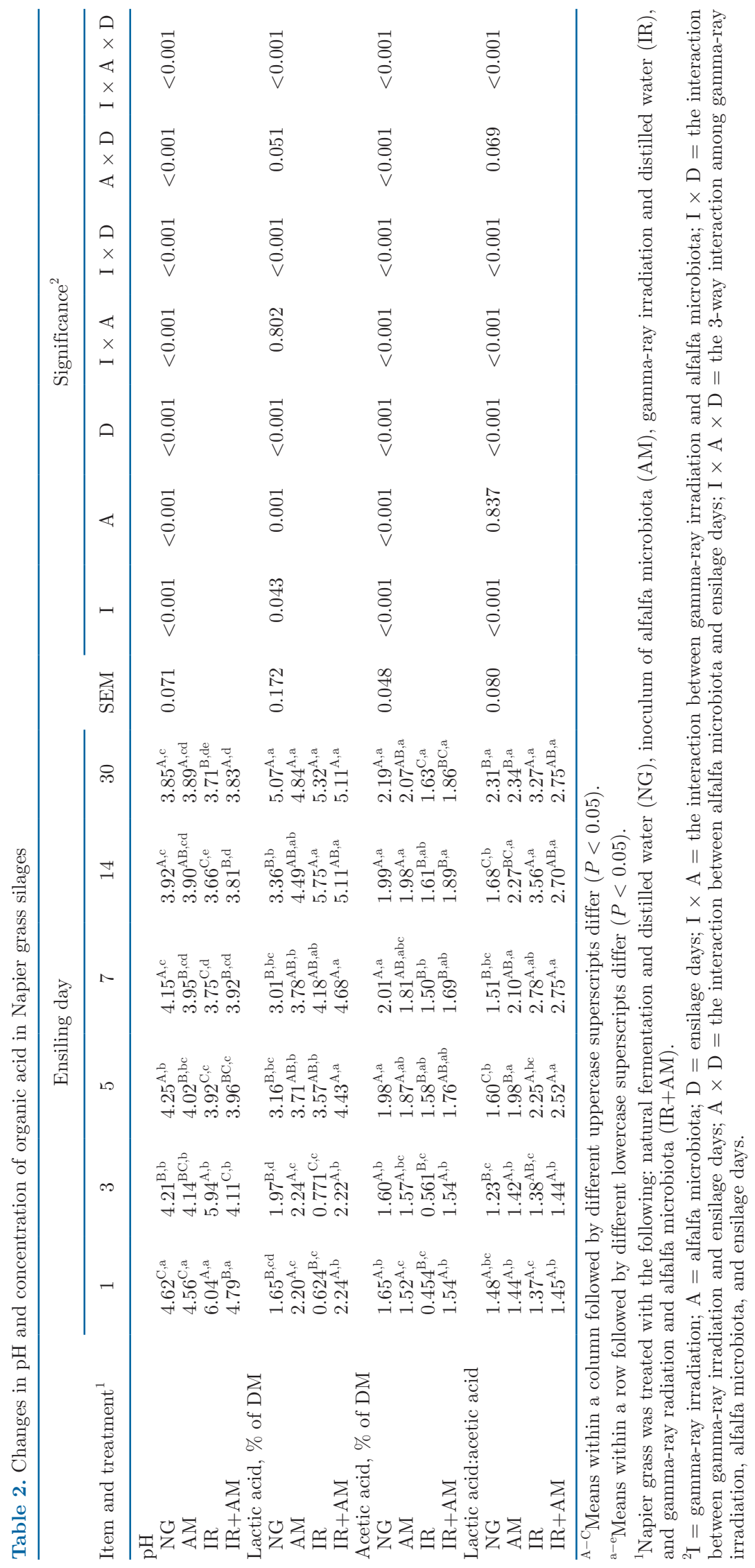


Dong et al.: EFFECT OF EXOGENOUS MICROBIOTA ON NAPIER GRASS SILAGES

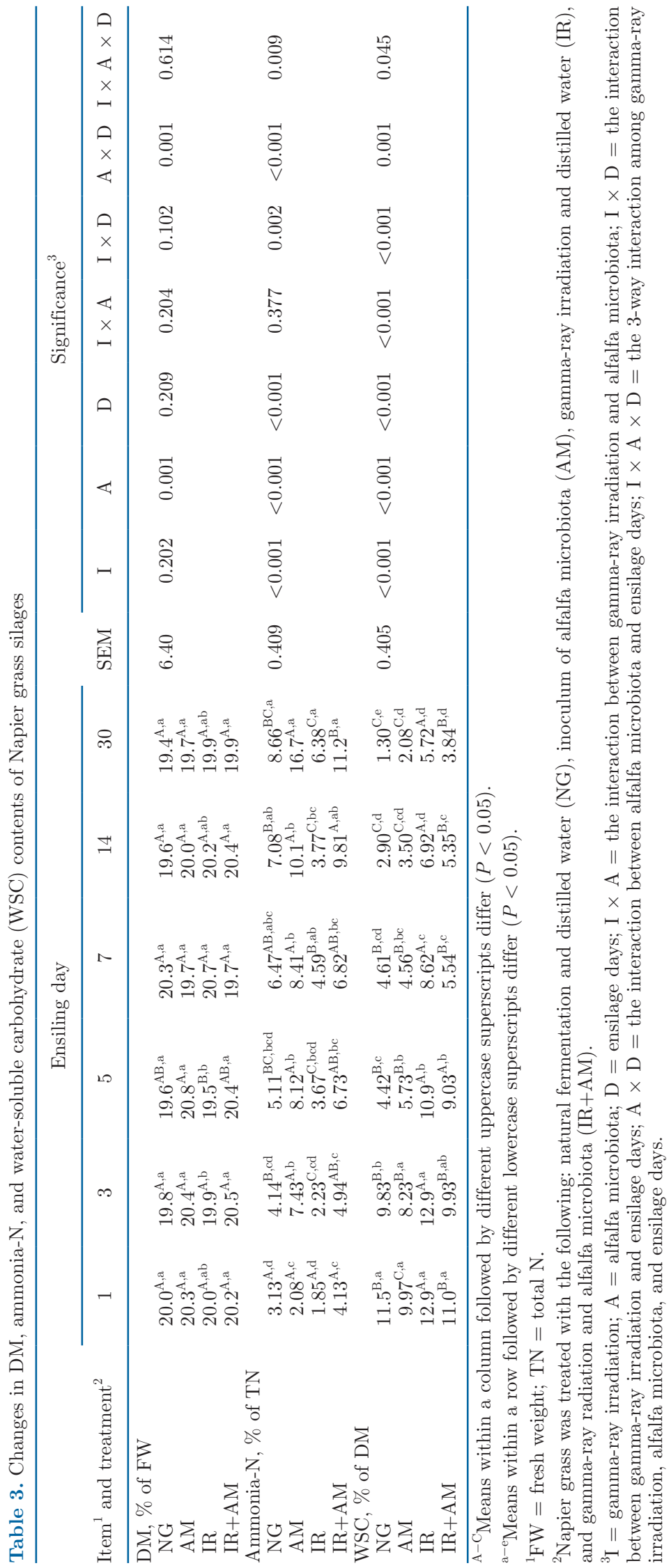




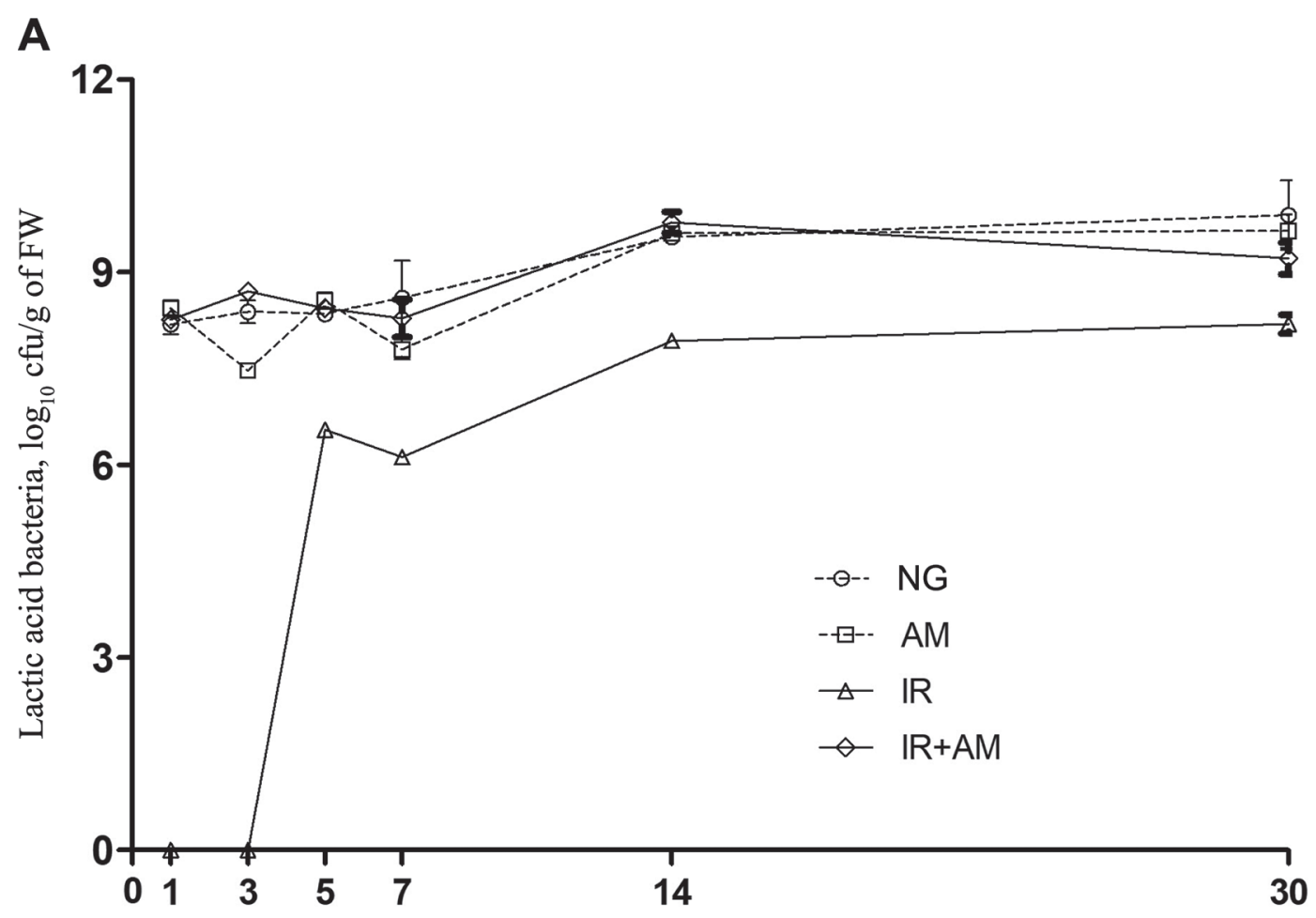

B

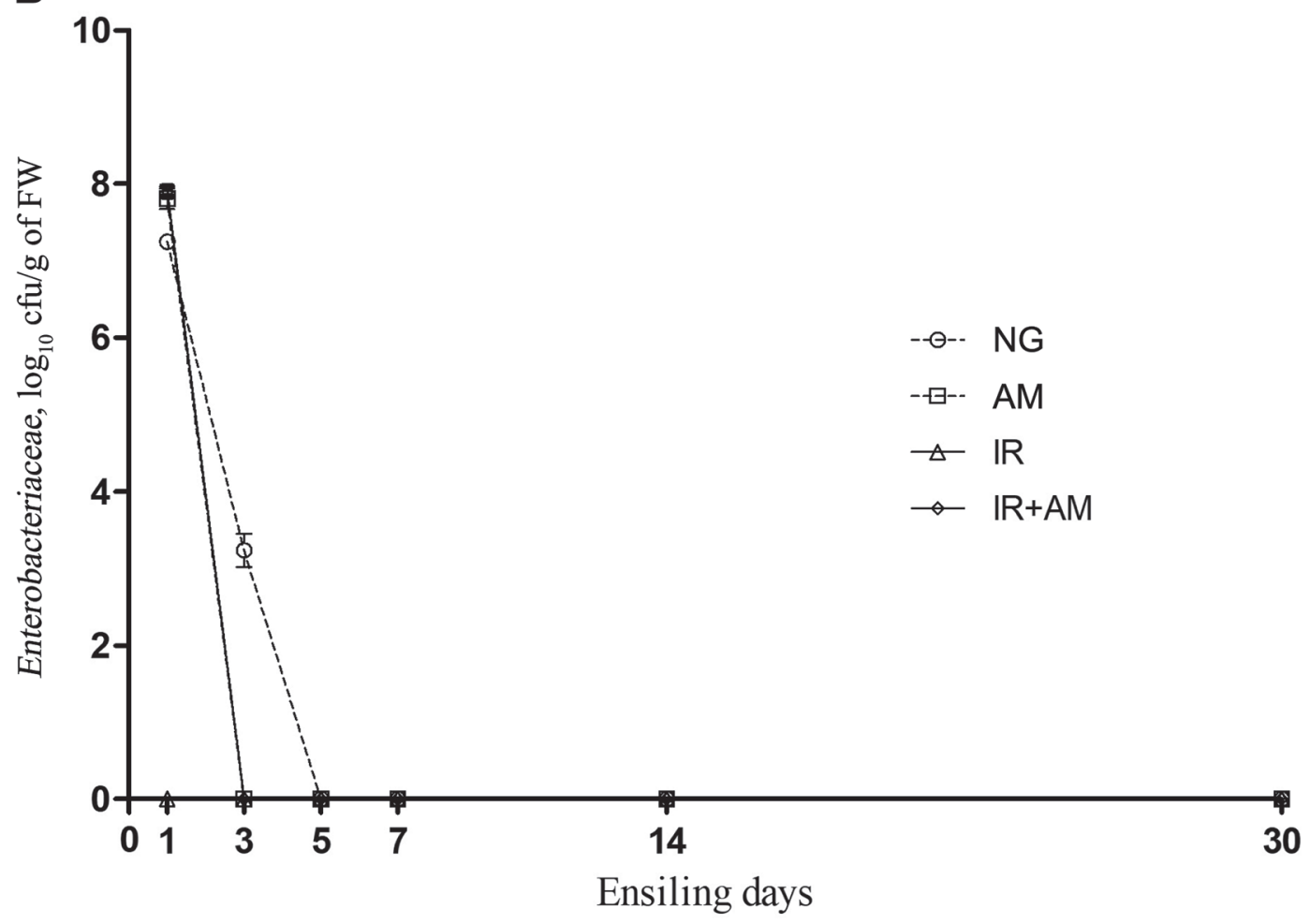

Figure 1. The dynamics of lactic acid bacteria (A) and Enterobacteriaceae (B) populations during the ensiling of Napier grass. Napier grass was treated with the following: natural fermentation and distilled water (NG), inoculum of alfalfa microbiota (AM), gamma-ray irradiation and distilled water (IR), and gamma-ray radiation and alfalfa microbiota (IR+AM). Error bars indicate SD. 
Table 4. Sample information, sequence abundance, and microbial diversity of the fresh Napier grass and alfalfa and the Napier grass silages

\begin{tabular}{|c|c|c|c|c|}
\hline $\begin{array}{l}\text { Treatment }{ }^{1} \text { and } \\
\text { ensiling days }\end{array}$ & $\begin{array}{l}\text { Sequence } \\
\text { number }\end{array}$ & Shannon & Chao1 & Coverage \\
\hline \multicolumn{5}{|l|}{ Fresh Napier grass } \\
\hline 0 & $45,596^{\mathrm{bcd}}$ & $2.79^{\mathrm{a}}$ & $129.08^{\mathrm{a}}$ & 0.9998 \\
\hline \multicolumn{5}{|l|}{ Fresh alfalfa } \\
\hline 0 & $43,477^{\mathrm{bcd}}$ & $1.63^{\mathrm{b}}$ & $93.83^{\mathrm{b}}$ & 0.9992 \\
\hline \multicolumn{5}{|l|}{ NG } \\
\hline 3 & $46,820^{\mathrm{abcd}}$ & $1.34^{\mathrm{b}}$ & $57.01^{\mathrm{c}}$ & 0.9996 \\
\hline 7 & $44,631^{\mathrm{bcd}}$ & $1.15^{\mathrm{b}}$ & $48.67^{\mathrm{cd}}$ & 0.9996 \\
\hline 30 & $39,403^{\mathrm{d}}$ & $1.11^{\mathrm{b}}$ & $57.73^{\mathrm{c}}$ & 0.9996 \\
\hline \multicolumn{5}{|l|}{$\mathrm{AM}$} \\
\hline 3 & $62,951^{\mathrm{ab}}$ & $0.97^{\mathrm{b}}$ & $55.97^{\mathrm{c}}$ & 0.9996 \\
\hline 7 & $60,593^{\mathrm{ab}}$ & $0.86^{\mathrm{b}}$ & $32.53^{\mathrm{d}}$ & 0.9997 \\
\hline 30 & $68,252^{\mathrm{a}}$ & $1.43^{\mathrm{b}}$ & $44.64^{\text {cd }}$ & 0.9997 \\
\hline \multicolumn{5}{|l|}{ IR } \\
\hline 5 & $49,147^{\mathrm{abcd}}$ & $0.09^{\mathrm{c}}$ & $30.15^{\mathrm{d}}$ & 0.9997 \\
\hline 7 & $49,063^{\text {abcd }}$ & $0.05^{\mathrm{c}}$ & $20.25^{\mathrm{e}}$ & 0.9998 \\
\hline 30 & $43,999^{\mathrm{cd}}$ & $0.06^{\mathrm{c}}$ & $32.46^{\mathrm{d}}$ & 0.9997 \\
\hline \multicolumn{5}{|l|}{$\mathrm{IR}+\mathrm{AM}$} \\
\hline 3 & $59,437^{\mathrm{abc}}$ & $0.91^{\mathrm{b}}$ & $53.64^{\mathrm{c}}$ & 0.9996 \\
\hline 7 & $39,066^{\mathrm{d}}$ & $1.04^{\mathrm{b}}$ & $58.23^{\mathrm{c}}$ & 0.9995 \\
\hline 30 & $42,697^{\mathrm{bcd}}$ & $0.98^{\mathrm{b}}$ & $48.22^{\mathrm{cd}}$ & 0.9996 \\
\hline
\end{tabular}

${ }^{\mathrm{a} e}$ Means within a column followed by different superscripts differ $(P<0.05)$.

${ }^{1}$ Napier grass was treated with the following: natural fermentation and distilled water (NG), inoculum of alfalfa microbiota (AM), gamma-ray irradiation and distilled water (IR), and gamma-ray radiation and alfalfa microbiota $(\mathrm{IR}+\mathrm{AM})$.

ferent treatments were different (Figure 5). Pediococcus was the dominant genus in the AM (75\%) and IR+AM (79\%) silages, whereas Lactobacillus and Leuconostoc were the predominant genera in NG silages, composing 31 and $55 \%$ of the bacterial community, respectively.

\section{DISCUSSION}

After gamma-ray radiation at $15 \mathrm{kGy}$ for $5 \mathrm{~h}$, the nutritional composition of Napier grass was unchanged, whereas no viable microorganisms were detected in sterile Napier grass. This indicated that gamma irradiation could kill microbes, providing the possibility of differentiating the effect of exogenous or epiphytic microbiota on the fermentation quality of silages in this study. Merry et al. (1995) also reported that no viable $\mathrm{LAB}$, enterobacteria, and clostridia were detected on sterilized herbage, whereas total WSC content (fructans, glucose, fructose, and sucrose) was similar between normal and sterile herbage. Oliveira et al. (2017) reported that LAB counts beyond $5 \mathrm{log} \mathrm{cfu} / \mathrm{g}$ of $\mathrm{FW}$ could ensure active silage fermentation. In the experiment, the LAB populations of both alfalfa and Napier grass before ensiling were higher than $5 \mathrm{log} \mathrm{cfu} / \mathrm{g}$ of FW. Thus, the transplantation of equivalent alfalfaoriginal microbiota to the Napier grass theoretically provided enough bacteria to initiate fermentation of the silage during the early stages of Napier grass ensiling.

\section{Effect of Alfalfa Microbiota on Fermentation Properties of Napier Grass Silages}

All silage samples exhibited typical LA-type fermentation, as defined by McDonald and Edwards (1976) and characterized by low $\mathrm{pH}$ value and high LA:AcA ratio. The higher LA concentration in IR+AM than in NG might be due to the higher relative abundance of the Pediococcus genus in IR+AM than in NG silages. However, it is unclear why inoculation with alfalfa inoculum increased the abundance of Pediococcus. The LA and AcA concentrations in IR silages remained at their initial values and were the lowest values measured during $3 \mathrm{~d}$ of ensiling, followed by a sharp increase to 3.57 and $1.58 \%$ of DM, respectively, on d 5 of ensiling. This indicated that the activity of epiphytic microorganisms was inhibited by gamma-ray radiation during the initial $3 \mathrm{~d}$ of ensiling; however, some bacteria could reactivate after a certain lag period because they have strong tolerance against gamma-ray radiation (Esmaeili et al., 2018).

Although the natural fermentation of Napier grass in the present study displayed LA-type fermentation, the AcA concentration in NG was higher than that in IR+AM silages after $7 \mathrm{~d}$ of ensiling. This discrepancy was solely attributed to microbiota sources. In the NG silages, Leuconostoc started silage fermentation and played a dominant role over the $30 \mathrm{~d}$ of ensiling. Leuconostoc is a heterofermentative LAB and can use 
the phosphoketolase pathway to produce a mixture of LA, AcA, and ethanol (Gallagher et al., 2018). This also partially confirmed the fact that AcA-producing bacteria could dominate silage fermentation of tropical grasses, as reported elsewhere (Catchpoole and Henzell, 1971).

The lowest ammonia- $\mathrm{N}$ content in IR silages was attributed to the gamma irradiation because no viable Clostridium was identified in gamma-irradiated Napier grass before ensiling. Inoculating alfalfa microbiota increased ammonia- $\mathrm{N}$ concentration compared with NG and IR silages after $3 \mathrm{~d}$ of ensiling. The results indicate that more microorganisms with proteolytic activity might be present in the alfalfa microbiota than in Napier grass microbiota. In the study, Clostridium sensu stricto 1 accounted for $5.39 \%$ of the bacterial community of fresh alfalfa before ensiling. Clostridium sensu stricto 1 was one genus of clostridia, which is known to be responsible for the high soluble $\mathrm{N}$ and ammonia-N in wet legume silages (Kung et al., 2018).

The highest WSC content in IR silages over $30 \mathrm{~d}$ of ensiling was ascribed to the inhibition of epiphytic microbiota by gamma-ray irradiation, which reduced the competition for fermentable substrates between exogenous and epiphytic microbiota. The delayed decrease in WSC content in IR silages matched the slow increase of LA and AcA during the initial $3 \mathrm{~d}$ of ensiling.
Viable cells of LAB in IR silages appeared on d 5 of ensiling and increased to $7.93 \log _{10} \mathrm{cfu} / \mathrm{g}$ of $\mathrm{FW}$ on $\mathrm{d}$ 14, whereas Enterobacteriaceae in IR silages was undetectable throughout the ensiling period. These results indicate that Enterobacteriaceae is more sensitive to gamma-ray irradiation than LAB. Jeong and Kang (2017) observed that gram-negative bacteria are more sensitive to ionizing irradiation than gram-positive bacteria and that the radiation resistance of gram-positive bacteria is caused by effective metabolic systems that repair cellular damage such as single- and double-strand breaks of DNA and base damage.

\section{Effect of Alfalfa Microbiota on Bacterial Community Composition and Diversity in Napier Grass Silages}

The Chao1 is an estimator of species richness based on the number of rare species, and the Shannon index is used to measure species diversity based on the number and evenness of species (Table 4). The IR silages had the lowest Shannon index and Chao1 among all silages over the ensiling period. Gamma-ray irradiation affects bacterial composition primarily through its mutagenic or lethal effect on irradiation-sensitive bacteria. Ensiling decreased the richness and diversity of the bacterial community, indicated by the lower Shannon index and Chaol in silages than in fresh Napier grass. Zheng

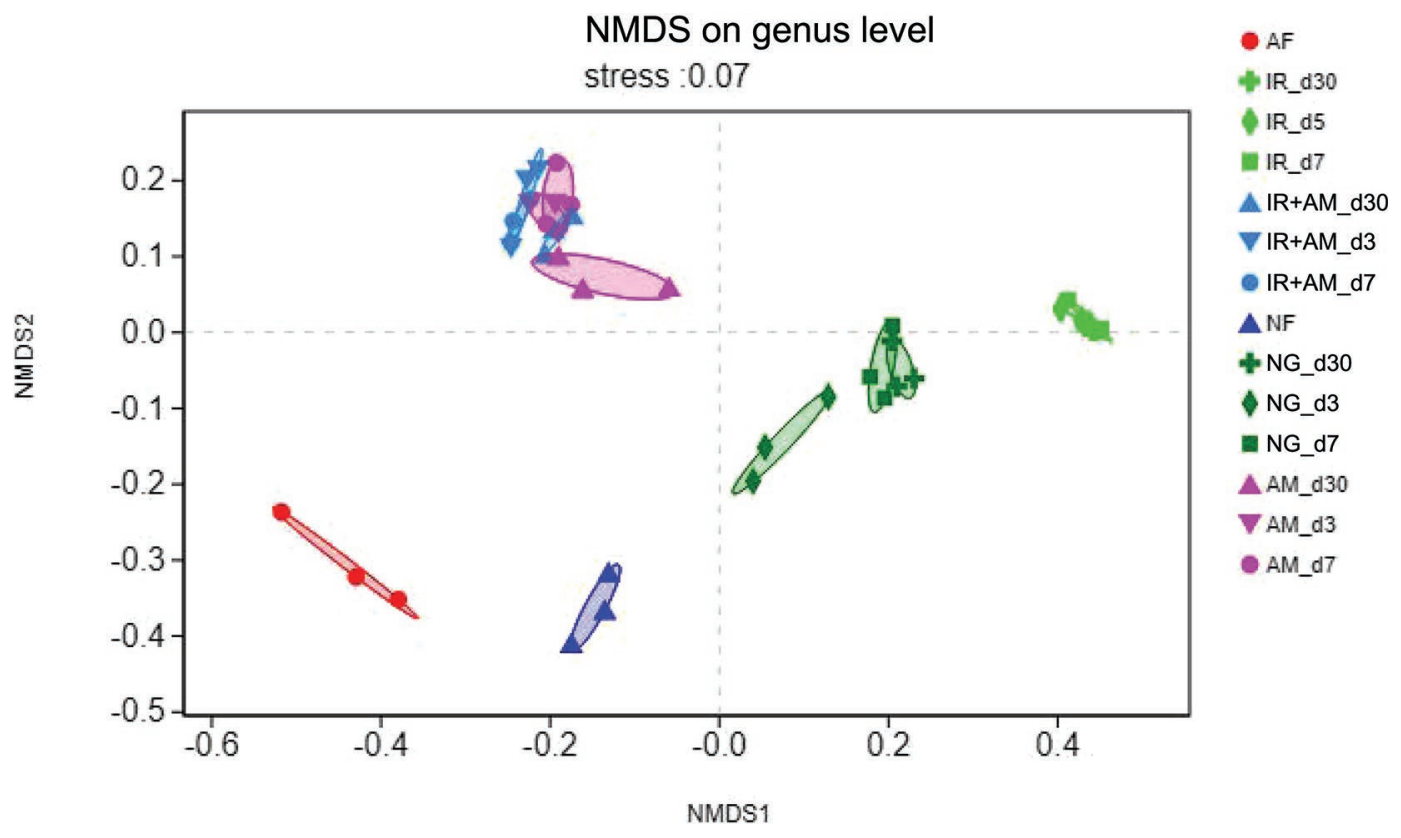

Figure 2. Nonmetric multidimensional scaling (NMDS) based on Bray-Curtis dissimilarity distance of the bacterial community between samples (stress $=0.07, \mathrm{R}^{2}=0.7821, P=0.001$ ). Napier grass was treated with the following: natural fermentation and distilled water (NG), inoculum of alfalfa microbiota (AM), gamma-ray irradiation and distilled water (IR), and gamma-ray radiation and alfalfa microbiota (IR+AM). $\mathrm{NF}=$ fresh Napier grass; $\mathrm{AF}=$ fresh alfalfa; $\mathrm{d}=$ ensiling day. 
et al. (2017) also found that the lower richness and diversity of the bacterial community in silage than in fresh alfalfa were related to the disappearance of some epiphytic bacteria due to their lower adaptability to the anaerobic and acidic conditions in such silage. MéndezGarcía et al. (2015) reported that the low pH was the main factor underlying limited microbial diversity in acid environments.

Nonmetric multidimensional scaling, based on BrayCurtis dissimilarity distance, was conducted to compare bacterial community compositions between treatments and ensiling durations (Figure 2). The separate cluster between fresh alfalfa and fresh Napier grass indicated that the differences in the distribution and structure of the bacterial community prevailed between Napier grass and alfalfa before ensiling. The separation of silages from fresh material was attributed to the suppression or inactivation of some epiphytic bacteria species during the ensiling process (Romero et al., 2017).

The IR silages were separated from the other silages, indicating that gamma-ray radiation affected the structure and succession of the bacterial community during ensiling. The AM and IR+AM silages were clustered together and were far from the NG and IR silages, showing that alfalfa microbiota affected the succession of the bacterial community during the ensiling of Napier grass regardless of irradiation. Mogodiniyai Kasmaei et al. (2017) also found that silages inoculated with the grass microbiota had a higher abundance of the Pediococcus genus than silages inoculated with the maize or clover microbiota and confirmed that microbiota source could affect bacterial community composition during ensiling.

The bacterial community of fresh alfalfa was dominated by Firmicutes, whereas Proteobacteria dominated the fresh Napier grass; however, Firmicutes became the most predominant phylum in Napier grass silages since the initiation of fermentation. This observation was corroborated by Romero et al. (2017), who reported that the abundance of Firmicutes and Proteobacteria showed an antagonistic relationship: Proteobacteria dominated $(84 \%)$ in fresh corn, whereas Firmicutes became the most abundant phylum $(86.0 \%)$ in whole-crop corn ensiled for 100 d. Firmicutes are important acid hydrolytic microorganisms in anaerobic environments, including anaerobic reactors and rumens (Zhao et al., 2017), and most the prevalent genera Lactobacillus, Lactococcus, and Weissella during ensiling belong to the phylum Firmicutes (Eikmeyer et al., 2013).

The higher abundance of the Pantoea genus in natural fermentation of Napier grass might partly contribute to

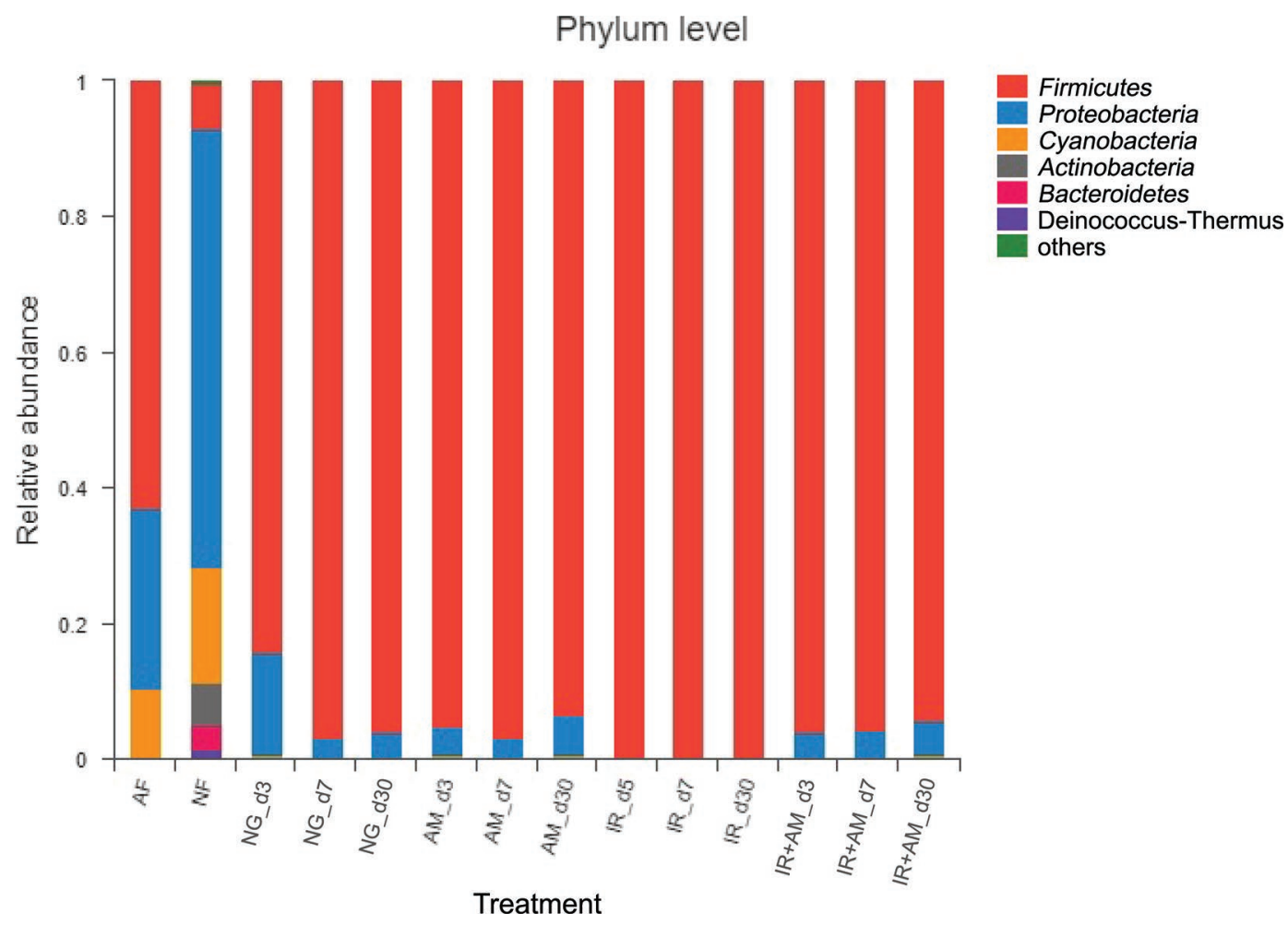

Figure 3. The bacterial community at phylum level during the ensiling of Napier grass. Napier grass was treated with the following: natural fermentation and distilled water (NG), inoculum of alfalfa microbiota (AM), gamma-ray irradiation and distilled water (IR), and gamma-ray radiation and alfalfa microbiota $(\mathrm{IR}+\mathrm{AM}) . \mathrm{NF}=$ fresh Napier grass; $\mathrm{AF}=$ fresh alfalfa; $\mathrm{d}=$ ensiling day. 
the lower ammonia-N content in NG silages. Ogunade et al. (2018) reported that Pantoea could reduce silage ammonia-N concentration; however, its role during ensiling warrants further research.

In the present study, although the relative abundance of Leuconostoc in both fresh Napier grass and alfalfa was $<1 \%$, Leuconostoc (64.29-49.04\%) dominated in NG silages. The high relative abundance of Leuconostoc was in agreement with the higher AcA content in NG silages.

Enterococcus was detected in $\mathrm{AM}$ and $\mathrm{IR}+\mathrm{AM}$ silages because of the inoculation of alfalfa microbiota, which was dominated by Enterococcus $(42.81 \%$ ) in fresh alfalfa. Ni et al. (2017) also found that Enterococcus was the dominant genus in pre-ensiled alfalfa, and its proportion increased to $>65 \%$ after ensiling. Although the abundance of Pediococcus was $<1 \%$ in both fresh Napier grass and alfalfa, Pediococcus was exclusively observed in the Napier grass silages inoculated with alfalfa microbiota and became the predominant genus over the whole ensiling period, reaching $82.34 \%$ on $d$ 7. Pediococci are commonly found in silage inoculants due to their tolerance to high $\mathrm{DM}$ and $\mathrm{pH}$ conditions, allowing them to dominate the initial stages of fermentation when the growth of lactobacilli is slow (Kung et al., 2003). Lin et al. (1992) investigated the succession of LAB during the ensiling of alfalfa and found that Pediococcus pentosaceus was the dominant LAB in the early stages of fermentation; however, Lactobacillus dominated the fermentation after $7 \mathrm{~d}$ of ensiling. For the natural fermentation of crops, LA-producing cocci (e.g., streptococci, leuconostocs, pediococci, lactococci, and enterococci) initiated lactate fermentation in silages, creating an anaerobic environment suitable for the development of lactobacilli (Cai et al., 1998). In the present study, Pediococcus outcompeted the indigenous microorganisms of Napier grass and exclusively dominated the ensiling of AM and IR+AM, whereas a slight increase in Lactobacillus was observed on d 30 of ensiling (relative abundance in each silage: 6.29 and $3.82 \%$, respectively). In the NG silages, Lactobacillus was the second dominant genus, increasing to $43.30 \%$ after $30 \mathrm{~d}$ of ensiling. The complementary action between Leuconostoc and Lactobacillus during ensiling might be responsible for the LA-type fermentation in Napier grass silages.

Lin et al. (1992) evaluated LAB succession in alfalfa and maize during the pre-ensiling and ensiling periods and found that the composition of epiphytic microorganisms could not predict the outcome of silage fermentation due to discrepancies in nutritional components such as WSC and buffering capacity profiles in pre-ensiled crops. In the present study, gamma-ray irradiation was adopted to ascertain the effects of forage microflora and nutritional composition on the outcome of silage fermentation; differences in bacterial com-

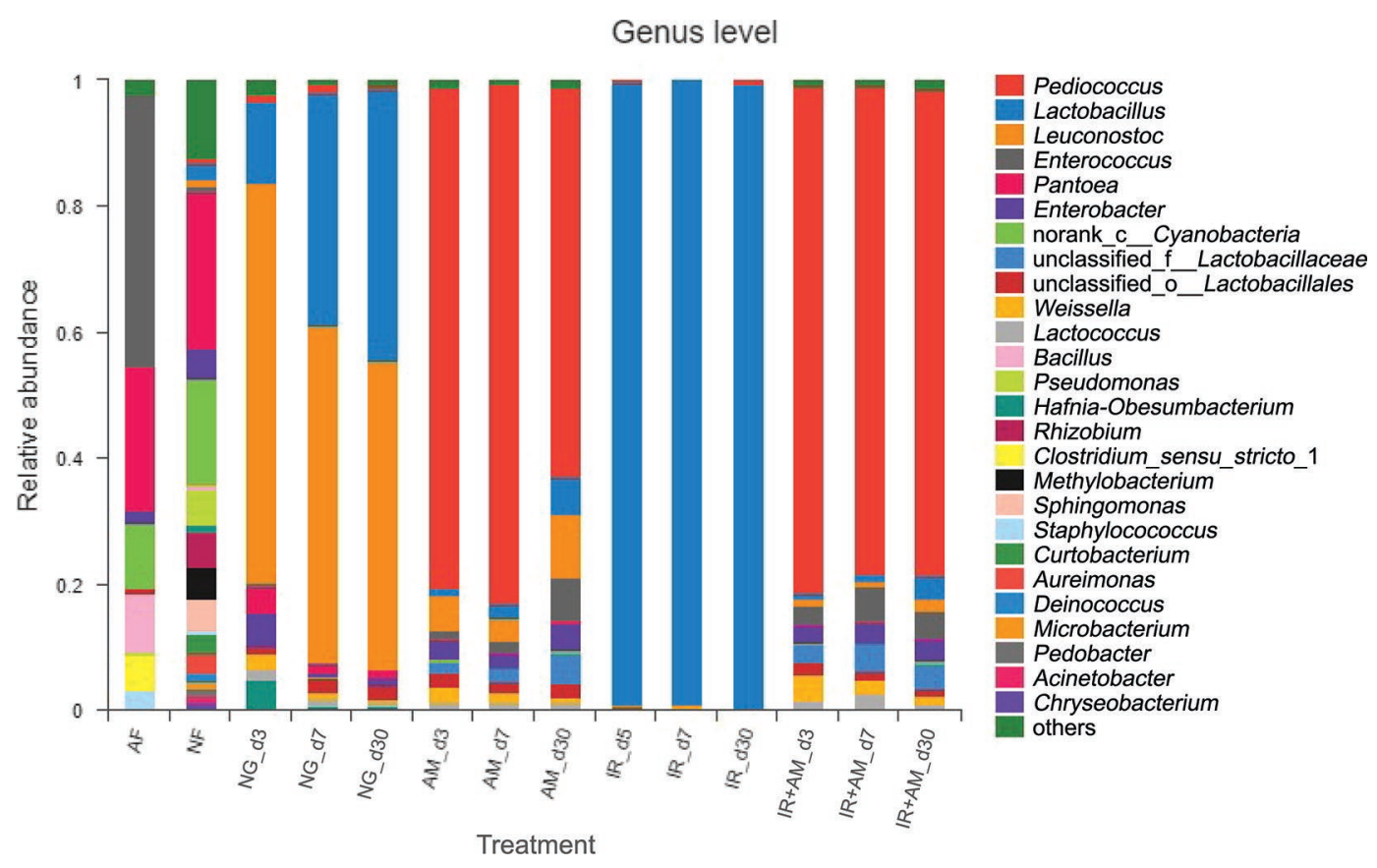

Figure 4. The bacterial community at genus level during the ensiling of Napier grass. Napier grass was treated with the following: natural fermentation and distilled water (NG), inoculum of alfalfa microbiota (AM), gamma-ray irradiation and distilled water (IR), and gamma-ray radiation and alfalfa microbiota $(\mathrm{IR}+\mathrm{AM}) . \mathrm{NF}=$ fresh Napier grass; $\mathrm{AF}=$ fresh alfalfa; $\mathrm{d}=$ ensiling day. 


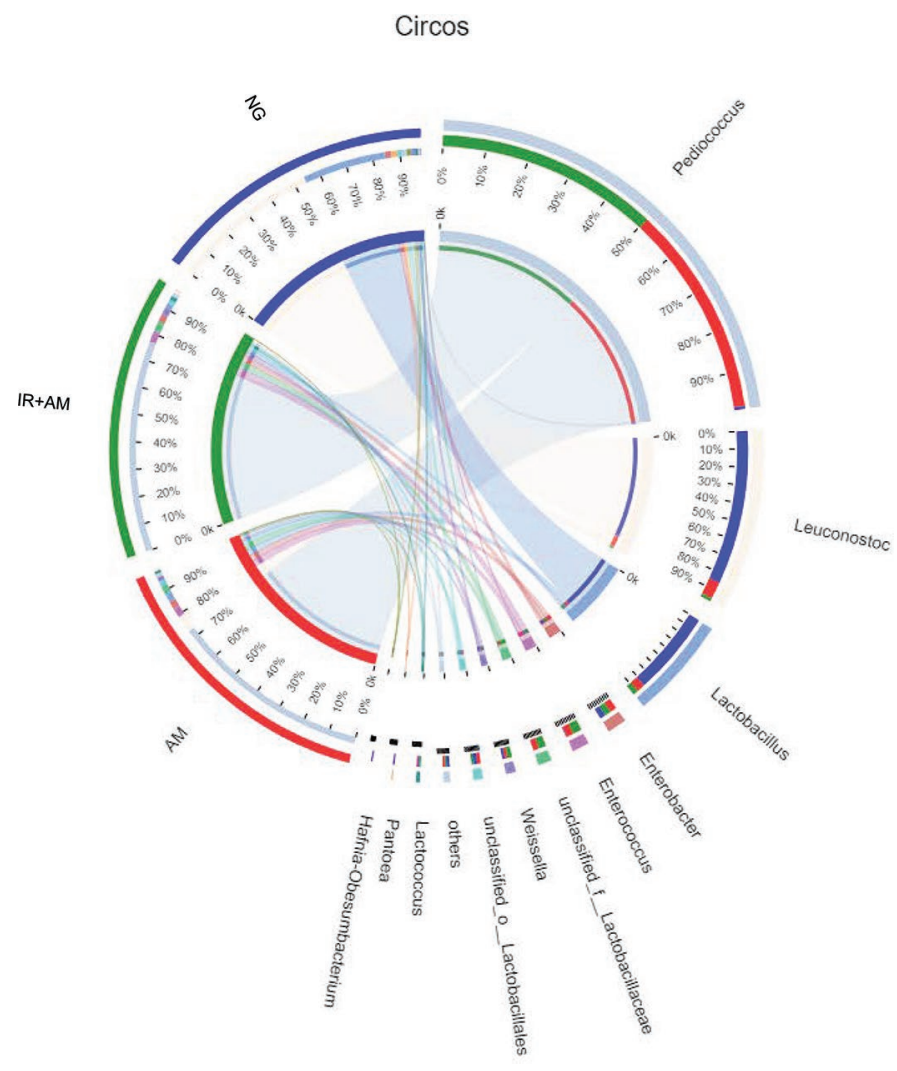

Figure 5. Circos plot depicting the relative diversity and abundance of bacteria among 30-d silages. Napier grass was treated with the following: natural fermentation and distilled water (NG), inoculum of alfalfa microbiota (AM), and gamma-ray radiation and alfalfa microbiota $(\mathrm{IR}+\mathrm{AM})$. The width of the bars represents the abundance of each taxon.

munity and fermentation quality during ensiling were mainly attributed to the source of the microbiota. A Circos graph was used to demonstrate the deviation of bacterial community composition among silages (Figure 5). The alfalfa microbiota markedly affected the relative abundance of LAB, mainly including Pediococcus, Leuconostoc, and Lactobacillus. The NG silage was dominated by Leuconostoc, followed by Lactobacillus, whereas Pediococcus dominated the bacterial community of IR+AM silages. All predominant genera on NG and IR+AM silages resided in AM silages. This indicated that the inoculation of alfalfa microbiota changed the bacterial community structure and component of silages regardless of irradiation, resulting in differences in fermentation characteristics. Although all treatments in this experiment exhibited LA-type fermentation, the higher AcA content in NG silages might be due to the high relative abundance of Leuconostoc, whereas Enterococcus and Pediococcus were responsible for the higher LA content in IR $+\mathrm{AM}$ silages. Inoculating exogenous microbiota could markedly affect bacterial community succession and end product concentration in Napier grass. It provided an alternative strategy for modulating the fermentation quality of forages; the epiphytic microbiota of readily fermentable forages could be used as a starter for non-readily fermentable forages to improve the quality of silage fermentation.

\section{CONCLUSIONS}

Inoculating with alfalfa microbiota affected the fermentation products and bacterial community succession of Napier grass silages. The natural fermentation of Napier grass was dominated by Leuconostoc and Lactobacillus, whereas Pediococcus outcompeted the indigenous microorganisms of Napier grass and exclusively dominated the ensiling of AM and IR+AM. Inoculating alfalfa microbiota to sterile Napier grass could decrease AcA concentration compared with NG silages; however, it increased the ammonia- $\mathrm{N}$ concentration compared with NG and IR silages after $3 \mathrm{~d}$ of ensiling.

\section{ACKNOWLEDGMENTS}

This work was partially supported by the National Key Research and Development Program of China (Beijing, China, grant no. 2017YFE0104300) and the National Natural Science Foundation of China (Beijing, China, grant no. 31872421). The authors have stated no conflicts of interest.

\section{REFERENCES}

Bao, W., Z. Mi, H. Xu, Y. Zheng, L. Y. Kwok, H. Zhang, and W. Zhang. 2016. Assessing quality of Medicago sativa silage by monitoring bacterial composition with single molecule, real-time sequencing technology and various physiological parameters. Sci. Rep. 6:28358. https://doi.org/10.1038/srep28358.

Broderick, G. A., and J. H. Kang. 1980. Automated simultaneous determination of ammonia and total amino acids in ruminal fluid and in vitro media. J. Dairy Sci. 63:64-75. https://doi.org/10 .3168/jds.S0022-0302(80)82888-8.

Cai, Y., Y. Benno, M. Ogawa, S. Ohmomo, S. Kumai, and T. Nakase. 1998. Influence of Lactobacillus spp. from an inoculant and of Weissella and Leuconostoc spp. from forage crops on silage fermentation. Appl. Environ. Microbiol. 64:2982-2987. https://doi.org/ 10.1128/AEM.64.8.2982-2987.1998.

Catchpoole, V. R., and E. F. Henzell. 1971. Silage and silage-making from tropical herbage species. Herbage 41:213-221.

Eikmeyer, F. G., P. Köfinger, A. Poschenel, S. Jünemann, M. Zakrzewski, S. Heinl, E. Mayrhuber, R. Grabherr, A. Pühler, H. Schwab, and A. Schlüter. 2013. Metagenome analyses reveal the influence of the inoculant Lactobacillus buchneri CD034 on the microbial community involved in grass ensiling. J. Biotechnol. 167:334-343. https://doi.org/10.1016/j.jbiotec.2013.07.021.

Esmaeili, S., M. Barzegar, M. A. Sahari, and S. Berengi-Ardestani. 2018. Effect of gamma irradiation under various atmospheres of packaging on the microbial and physicochemical properties of turmeric powder. Radiat. Phys. Chem. 148:60-67. https://doi.org/10 .1016/j.radphyschem.2018.02.028.

Feng, L., E. F. Kristensen, V. Moset, A. J. Ward, and H. B. Moller. 2018. Ensiling of tall fescue for biogas production: Effect of stor- 
age time, additives and mechanical pretreatment. Energy Sustain. Dev. 47:143-148. https://doi.org/10.1016/j.esd.2018.10.001.

Gallagher, D., D. Parker, D. J. Allen, and N. Tsesmetzis. 2018. Dynamic bacterial and fungal microbiomes during sweet sorghum ensiling impact bioethanol production. Bioresour. Technol. 264:163173. https://doi.org/10.1016/j.biortech.2018.05.053.

Jeong, S. G., and D. H. Kang. 2017. Inactivation of Escherichia coli O157:H7, Salmonella Typhimurium, and Listeria monocytogenes in ready-to-bake cookie dough by gamma and electron beam irradiation. Food Microbiol. 64:172-178. https://doi.org/10.1016/j .fm.2016.12.017.

Kim, K.-H., and S. Uchida. 1991. Comparative studies of ensiling characteristics between temperate and tropical species: 2. Mechanical pretreatments and changes in water soluble carbohydrate fractions during ensilage. J. Japan Grassl. Sci. 36:426-433.

Krishnamoorthy, U., T. V. Muscato, C. J. Sniffen, and P. J. Van Soest. 1982. Nitrogen fractions in selected feedstuffs. J. Dairy Sci. 65:217-225. https://doi.org/10.3168/jds.S0022-0302(82)82180-2.

Kung, L. 1998. A review on silage additives and enzymes. Pages 121135 in Proc. 59th Minneapolis Nutrition Conference, Minneapolis, MN. Department of Animal Science, University of Minnesota, St. Paul.

Kung, L., Jr., R. D. Shaver, R. J. Grant, and R. J. Schmidt. 2018. Silage review: Interpretation of chemical, microbial, and organoleptic components of silages. J. Dairy Sci. 101:4020-4033. https:// doi.org/10.3168/jds.2017-13909.

Kung, L., Jr., M. R. Stokes, and C. Lin. 2003. Silage additives. Pages 305-360 in Silage Science and Technology. Vol. 42. D. R. Buxton, R. E. Muck, and J. H. Harrison, ed. American Society of Agronomy, Madison, WI.

Li, J., X. Yuan, S. T. Desta, Z. Dong, W. Mugabe, and T. Shao. 2018. Characterization of Enterococcus faecalis JF85 and Enterococcus faecium Y83 isolated from Tibetan yak (Bos grunniens) for ensiling Pennisetum sinese. Bioresour. Technol. 257:76-83. https://doi .org/10.1016/j.biortech.2018.02.070.

Lin, C., K. K. Bolsen, B. E. Brent, R. A. Hart, J. T. Dickerson, A. M. Feyerherm, and W. R. Aimutis. 1992. Epiphytic microflora on alfalfa and whole-plant corn. J. Dairy Sci. 75:2484-2493. https:// doi.org/10.3168/jds.S0022-0302(92)78010-2.

McDonald, P., and R. A. Edwards. 1976. The influence of conservation methods on digestion and utilization of forages by ruminants. Proc. Nutr. Soc. 35:201-211. https://doi.org/10.1079/PNS19760033.

Méndez-García, C., A. I. Pelaez, V. Mesa, J. Sanchez, O. V. Golyshina, and M. Ferrer. 2015. Microbial diversity and metabolic networks in acid mine drainage habitats. Front. Microbiol. 6:475.

Merry, R. J., A. L. Winters, P. I. Thomas, M. Muller, and T. Muller. 1995. Degradation of fructans by epiphytic and inoculated lacticacid bacteria and by plant enzymes during ensilage of normal and sterile hybrid ryegrass. J. Appl. Bacteriol. 79:583-591. https://doi .org/10.1111/j.1365-2672.1995.tb00941.x.

Mertens, D. R. 2002. Gravimetric determination of amylase-treated neutral detergent fiber in feeds with refluxing in beakers or crucibles: Collaborative study. J. AOAC Int. 85:1217-1240.

Mogodiniyai Kasmaei, K., J. Dicksved, R. Spörndly, and P. Udén. 2017. Separating the effects of forage source and field microbiota on silage fermentation quality and aerobic stability. Grass Forage Sci. 72:281-289. https://doi.org/10.1111/gfs.12238

Ni, K., F. Wang, B. Zhu, J. Yang, G. Zhou, Y. Pan, Y. Tao, and J. Zhong. 2017. Effects of lactic acid bacteria and molasses additives on the microbial community and fermentation quality of soybean silage. Bioresour. Technol. 238:706-715. https://doi.org/10.1016/j biortech.2017.04.055.

Nishino, N., Y. Li, C. Wang, and S. Parvin. 2012. Effects of wilting and molasses addition on fermentation and bacterial community in guinea grass silage. Lett. Appl. Microbiol. 54:175-181. https:// doi.org/10.1111/j.1472-765X.2011.03191.x.

Ogunade, I. M., Y. Jiang, D. H. Kim, A. A. P. Cervantes, K. G. Arriola, D. Vyas, Z. G. Weinberg, K. C. Jeong, and A. T. Adesogan. 2017. Fate of Escherichia coli O157:H7 and bacterial diversity in corn silage contaminated with the pathogen and treated with chemical or microbial additives. J. Dairy Sci. 100:1780-1794. https://doi.org/10.3168/jds.2016-11745.

Ogunade, I. M., Y. Jiang, A. A. Pech Cervantes, D. H. Kim, A. S Oliveira, D. Vyas, Z. G. Weinberg, K. C. Jeong, and A. T. Adesogan. 2018. Bacterial diversity and composition of alfalfa silage as analyzed by Illumina MiSeq sequencing: Effects of Escherichia coli O157:H7 and silage additives. J. Dairy Sci. 101:2048-2059. https://doi.org/10.3168/jds.2017-12876.

Oliveira, A. S., Z. G. Weinberg, I. M. Ogunade, A. A. P. Cervantes, K. G. Arriola, Y. Jiang, D. Kim, X. Li, M. C. M. Goncalves, D. Vyas, and A. T. Adesogan. 2017. Meta-analysis of effects of inoculation with homofermentative and facultative heterofermentative lactic acid bacteria on silage fermentation, aerobic stability, and the performance of dairy cows. J. Dairy Sci. 100:4587-4603. https://doi .org/10.3168/jds.2016-11815.

Peng, K., L. Jin, Y. D. Niu, Q. Q. Huang, T. A. McAllister, H. E. Yang, H. Denise, Z. J. Xu, S. Acharya, S. X. Wang, and Y. X. Wang. 2018. Condensed tannins affect bacterial and fungal microbiomes and mycotoxin production during ensiling and upon aerobic exposure. Appl. Environ. Microbiol. 84:e02274-17.

Romero, J. J., Y. Zhao, M. A. Balseca-Paredes, F. Tiezzi, E. Gutierrez-Rodriguez, and M. S. Castillo. 2017. Laboratory silo type and inoculation effects on nutritional composition, fermentation, and bacterial and fungal communities of oat silage. J. Dairy Sci. 100:1812-1828. https://doi.org/10.3168/jds.2016-11642.

Staley, C., A. Khoruts, and M. J. Sadowsky. 2017. Contemporary applications of fecal microbiota transplantation to treat intestinal diseases in humans. Arch. Med. Res. 48:766-773. https://doi.org/ 10.1016/j.arcmed.2017.11.006.

Thomas, T. A. 1977. An automated procedure for the determination of soluble carbohydrates in herbage. J. Sci. Food Agric. 28:639-642. https://doi.org/10.1002/jsfa.2740280711.

Van Soest, P. J., J. B. Robertson, and B. A. Lewis. 1991. Methods for dietary fiber, neutral detergent fiber, and nonstarch polysaccharides in relation to animal nutrition. J. Dairy Sci. 74:3583-3597.

Yang, L., X. Yuan, J. Li, Z. Dong, and T. Shao. 2019. Dynamics of microbial community and fermentation quality during ensiling of sterile and nonsterile alfalfa with or without Lactobacillus plantarum inoculant. Bioresour. Technol. 275:280-287. https://doi.org/ 10.1016/j.biortech.2018.12.067.

Zhao, X., J. Liu, J. Liu, F. Yang, W. Zhu, X. Yuan, Y. Hu, Z. Cui, and X. Wang. 2017. Effect of ensiling and silage additives on biogas production and microbial community dynamics during anaerobic digestion of switchgrass. Bioresour. Technol. 241:349-359. https:// doi.org/10.1016/j.biortech.2017.03.183.

Zheng, M. L., D. Z. Niu, D. Jiang, S. S. Zuo, and C. C. Xu. 2017. Dynamics of microbial community during ensiling direct-cut alfalfa with and without LAB inoculant and sugar. J. Appl. Microbiol. 122:1456-1470. https://doi.org/10.1111/jam.13456. 